\title{
Chromium and energy restriction as substitutes for ractopamine in finishing gilts diet
}

\author{
Taynah Vieira Aguiar Farias ${ }^{1}$ (D) Charles Kiefer ${ }^{*}$ (D) Karina Marcia Ribeiro de Souza Nascimento ${ }^{1}$ (D) \\ Anderson Corassa ${ }^{2}$ (D) Stephan Alexander da Silva Alencar' (D) Gabriela Puhl Rodrigues ${ }^{1}$ (D) \\ Jéssica Lira da Silva ${ }^{1}$ Alexandre Pereira dos Santos $^{1}$ (D)
}

'Programa de Pós-graduação em Ciência Animal, Universidade Federal de Mato Grosso do Sul (UFMS), 79070-900, Campo Grande, MS, Brasil. E-mail: charles.kiefer@ufms.br. "Corresponding author.

${ }^{2}$ Universidade Federal de Mato Grosso (UFMT), Sinop, MT, Brasil.

ABSTRACT: This study evaluated chromium supplements and energy restriction as substitutes for ractopamine in the diets of late finishing gilts. Sixty gilts were used, with initial weights of $98.87 \pm 0.25 \mathrm{~kg}$ and final weights of $122.69 \pm 10.97 \mathrm{~kg}$, distributed in a randomized block design with five diets: control; yeast chromium (0.8 ppm); chromium picolinate (0.48 ppm); ractopamine (20 ppm) and energy restriction (reduction of $150 \mathrm{kcal}$ of EM kg-1 of feed), with six replicates and two animals per experimental unit. Feeding diet containing ractopamine enabled better $(P<0.05)$ feed conversion and greater weights of the hot carcass of the gilts. The diet containing ractopamine exhibited a lower $(P<0.05)$ cost of feed per kilogram of gain and higher economic efficiency, when compared to diets containing chromium and energy restriction; these exhibited better outcomes, compared to the control diet. Diets supplemented with chromium and ractopamine resulted in a higher $(P<0.05)$ percentage and quantity of lean meat and a higher rate of carcass bonus, when compared to the control diet and energy restriction. The energy reduction did not harm the gilts' responses, compared to the control diet. Ractopamine supplementation allowed for a better feed conversion, lower feed cost per kilogram of gain, and a higher economic efficiency index. Supplements of chromium and ractopamine increased the percentage and quantity of lean meat and the bonus index of the carcasses. Therefore, chromium picolinate and chromium yeast are potential substitutes for ractopamine for optimizing the gilts carcass characteristics.

Key words: beta-adrenergic, carcass, energy, lean meat, minerals.

Cromo e restrição energética em substituição a ractopamina na dieta de leitoas em terminação tardia

RESUMO: Realizou-se este estudo com o objetivo de avaliar as suplementações de cromo e a restrição energética em substituição a

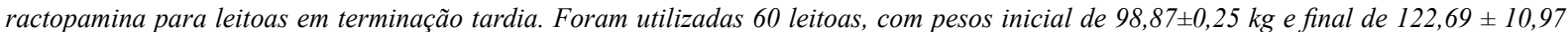
$\mathrm{kg}$, distribuidas em delineamento de blocos ao acaso com cinco dietas: controle; cromo levedura (0,8 ppm); picolinato de cromo (0,48 ppm); ractopamina (20 ppm) e restrição energética (redução de $150 \mathrm{kcal}^{\text {de EM }} \mathrm{kg}^{-1}$ de ração), com seis repetições e dois animais por unidade experimental. A dieta contendo ractopamina proporcionou melhor $(P<0,05)$ conversão alimentar e maior peso de carcaça quente das leitoas. A dieta contendo ractopamina apresentou menor $(P<0,05)$ custo de ração por quilograma de ganho e maior indice de eficiência econômica em relação as dietas contendo cromo e restrição energética que, por sua vez, foram superiores em comparação a dieta controle. Dietas suplementadas com cromo e ractopamina apresentaram maior $(P<0,05)$ percentual e quantidade de carne magra e maior indice de bonificação de carcaça em relação a dieta controle e restrição energética. Concluiu-se que a redução energética não prejudica as respostas das leitoas em relação a dieta controle. A suplementação de ractopamina possibilita melhor conversão alimentar, menor custo de ração por quilograma de ganho e maior índice de eficiência econômica. As suplementações de cromo e ractopamina expressam aumento do percentual e quantidade de carne magra e do índice de bonificação das carcaças. O picolinato de cromo e o cromo levedura são potenciais substitutos a ractopamina para otimizar as características de carcaça das leitoas.

Palavras-chave: beta-adrenérgico, características decarcaça, carne magra, energia, minerais.

\section{INTRODUCTION}

Ractopamine has positive effects on performance (LEAL et al., 2015) and pig carcass characteristics (RICHARD et al., 2017). It functions through the $\beta$-specific receptors, resulting in a decrease in lipogenesis and an increase in muscle mass (ALMEIDA et al., 2012). Despite the benefits of ractopamine in improving the performance and carcass characteristics of pigs, its use is questioned and prohibited in some countries (FERREIRA et al., 2011).

Alternatives to replace ractopamine in pig diets have been evaluated. They included betaine (SALES, 2011), conjugated linoleic acid 
(CLA) (SAAVEDRA et al., 2019), and safflower and coconut oils (COSTA et al., 2020). Chromium is a potential alternative (CARAMORI JÚNIOR. et al., 2017, RODRIGUES et al., 2020). Chromium acts as a glucose tolerance factor (GTF), increasing the fluidity of the cell membrane, enabling the insulin receptor binding (EVANS \& BOWMAN, 1992) and promoting the synthesis of muscle proteins. A greater proportion of the metabolized glucose will be converted into energy, with greater absorption of amino acids (PARK et al., 2009), favoring the deposition of protein in the carcass.

Chromium supplementation has positive effects of on the performance and carcass characteristics of castrated male pigs in the finishing phase (CARAMORI JÚNIOR et al., 2017); however, few studies have simultaneously evaluated the effects of chromium supplementation and energy restriction, in comparison with ractopamine supplementation. Therefore, this study aimed to evaluate and compare chromium supplements and energy restriction as alternatives to ractopamine in the diet of late finishing gilts.

\section{MATERIALS AND METHODS}

Sixty gilts (Duroc / Pietrain x Large White / Landrace) with initial weights of $98.87 \pm 8.13 \mathrm{~kg}$ and final weights of $122.69 \pm 10.97 \mathrm{~kg}$ were housed in a masonry shed, covered with ceramic tiles, screened sides, and fully compact floor. The pens, with an area of $2.94 \mathrm{~m}^{2}$, were equipped with a semi-automatic feeder, nipple-type drinker, and were cleaned twice a day by removing feces and urine that were moved to the bottom of the pen. Females were fed two to three times a day using the semi-automatic feeders.

The animals were distributed in a randomized block design with five diets: control, yeast chromium $(0.8 \mathrm{ppm})$, chromium picolinate (0.48 ppm), ractopamine (20 ppm), and energy restriction (reduction of $150 \mathrm{kcal}^{\mathrm{E}} \mathrm{EM} \mathrm{kg} \mathrm{of} \mathrm{feed),}^{-1}$, with six replicates and two animals per experimental unit. The initial weight was adopted as the blocking criterion for block formation.

The experimental diets (Table 1) were formulated based on the ideal protein concept, using corn and soybean meal, to meet the nutritional requirements of gilts with high genetic potential, according to the proposed recommendations (ROSTAGNO et al., 2017). Nutritional levels were the same between the experimental diets, except for the energy level of the energy-restricted diet, which was modified to reduce the energy levels by $150 \mathrm{kcal}$ $\mathrm{kg}^{-1}$ by replacing soybean oil with an inert material (kaolin). Rations and water were provided ad libitum throughout the experimental period.

Feed waste and leftovers of the feeders were collected and quantified to determine the daily feed consumption. The daily consumption of metabolizable energy, crude protein, and ileal digestible lysine was estimated based on the determined daily feed intake and the estimated nutritional concentration of the experimental diets. The feed conversion was calculated considering the feed consumption and weight gain of the animals during the experimental period.

The air temperature, temperature of the black globe, and relative humidity of the air were monitored daily at $08: 00$ and $16: 00 \mathrm{~h}$; they were at $25.6 \pm 4.80{ }^{\circ} \mathrm{C}, 70.3 \pm 10.8 \%$, and $25,9 \pm 4.8{ }^{\circ} \mathrm{C}$, respectively. The calculated black globe temperature and humidity index were $76.3 \pm 1.70$.

The animals were weighed on an electronic scale at the beginning and at the end of the experimental period. After the final weighing, the animals were allowed to fast for $12 \mathrm{~h}$, loaded onto a truck, and transported to a commercial abattoir. At the slaughter plant, the animals were housed in collective waiting pens with free access to water. Slaughter took place following the management rules and procedures, in accordance with regulation (MAPA, 2018).

At the end of the slaughter line, the carcasses were weighed to obtain the hot carcass weight and separated into two bands by a longitudinal cut in the line corresponding to the spine. At point $\mathrm{P} 2$, on the left band of the carcass, the fat thickness, Longissimus dorsi muscle depth, and the percentage of lean meat were determined using the Hennessy Granding System electronic type gun. The amount of lean meat in the carcass was calculated based on the weight of the hot carcass and the percentage of lean meat. The bonus index was calculated using the equation: $\mathrm{BI}=23.6+(0.286 \times$ hot carcass weight $)+$ estimated meat percentage in the carcass (BRIDI \& SILVA, 2007).

The economic analysis of the diets was carried out; the cost of feed per kilogram of weight gain (CWG) of the animals was calculated using the adapted equation of BELLAVER et al. (1985): $\mathrm{Yi}=$ $(\mathrm{Qi} \times \mathrm{Pi}) / \mathrm{Gi}$, where $\mathrm{Yi}$ is the feed cost per kilogram of pig gain in the $i^{\text {th }}$ treatment; $\mathrm{Qi}=$ amount of feed consumed in the $\mathrm{i}^{\text {th }}$ treatment; $\mathrm{Pi}=$ price per kilogram of feed used in the $\mathrm{i}^{\text {th }}$ treatment; and $\mathrm{Gi}$ = pig gain in the $\mathrm{i}^{\text {th }}$ treatment. The economic efficiency index (EEI) was calculated according to the adapted equation of 
Table 1 - Centesimal and nutritional composition of experimental diets.

\begin{tabular}{|c|c|c|c|c|c|}
\hline \multirow[t]{2}{*}{ Ingredients, $\mathrm{g} \mathrm{kg}^{-1}$} & \multicolumn{5}{|c|}{--------1 } \\
\hline & Control & Energetic restriction & Ractopamine & Chromium yeast & Chromium picolinate \\
\hline Corn $7.86 \%$ & 811.7 & 811.7 & 811.7 & 811.7 & 811.7 \\
\hline Soybean meal, $46.5 \%$ & 142.3 & 142.3 & 142.3 & 142.3 & 142.3 \\
\hline Soybean oil & 18.00 & 0.00 & 18.00 & 18.00 & 18.00 \\
\hline Dicalcium phosphate & 9.66 & 9.66 & 9.66 & 9.66 & 9.66 \\
\hline Limestone & 6.21 & 6.21 & 6.21 & 6.21 & 6.21 \\
\hline L-Lysine $\mathrm{HCl}$ & 3.82 & 3.82 & 3.82 & 3.82 & 3.82 \\
\hline Salt & 3.55 & 3.55 & 3.55 & 3.55 & 3.55 \\
\hline Premix vit $+\min ^{1}$ & 1.50 & 1.50 & 1.50 & 1.50 & 1.50 \\
\hline Inert (kaolin) & 1.00 & 19.00 & 0.00 & 0.50 & 0.996 \\
\hline L-Treonine & 0.97 & 0.97 & 0.97 & 0.97 & 0.97 \\
\hline DL-Metionine & 0.85 & 0.85 & 0.85 & 0.85 & 0.85 \\
\hline L-Triptofan & 0.38 & 0.38 & 0.38 & 0.38 & 0.38 \\
\hline Ractopamine $^{2}$ & 0.00 & 0.00 & 1.00 & 0.00 & 0.00 \\
\hline Chromium yeast ${ }^{3}$ & 0.00 & 0.00 & 0.00 & 0.50 & 0.00 \\
\hline Chromium picolinate $^{4}$ & 0.00 & 0.00 & 0.00 & 0.00 & 0.004 \\
\hline \multicolumn{6}{|c|}{ - } \\
\hline Crude protein, $\mathrm{g} \mathrm{kg}^{-1}$ & 135.0 & 135.0 & 135.0 & 135.0 & 135.0 \\
\hline Metabolizable energy, $\mathrm{kcal} \mathrm{kg}^{-1}$ & 3,350 & 3,200 & 3,350 & 3,350 & 3,350 \\
\hline Digestible lysine, $\mathrm{g} \mathrm{kg}^{-1}$ & 0.811 & 0.811 & 0.811 & 0.811 & 0.811 \\
\hline Digestible meth+cyst, $\mathrm{g} \mathrm{kg}^{-1}$ & 4.87 & 0.487 & 0.487 & 0.487 & 0.487 \\
\hline Digestible treonine, $\mathrm{g} \mathrm{kg}^{-1}$ & 5.27 & 5.27 & 0.527 & 0.527 & 0.527 \\
\hline Digestible tryptophan, $\mathrm{g} \mathrm{kg}^{-1}$ & 0.162 & 0.162 & 0.162 & 0.162 & 0.162 \\
\hline Calcium, $\mathrm{g} \mathrm{kg}^{-1}$ & 0.545 & 0.545 & 0.545 & 0.545 & 0.545 \\
\hline Digestible phosphorus, $\mathrm{g} \mathrm{kg}^{-1}$ & 0.262 & 0.262 & 0,262 & 0,262 & 0,262 \\
\hline Sodium, $\mathrm{g} \mathrm{kg}^{-1}$ & 0.160 & 0.160 & 0.160 & 0.160 & 0.160 \\
\hline
\end{tabular}

${ }^{1}$ Content per kg of product: vitamin A: 5.000.000 UI, vitamin D3: 1.000 .000 UI, vitamin E: 25.000 UI, vitamin K3: 3.000 mg, vitamin B1: $1.500 \mathrm{mg}$, vitamin B2: $4.000 \mathrm{mg}$, vitamin B6: $1.500 \mathrm{mg}$, vitamin B12: $18.000 \mathrm{mg}$, niacin: $18 \mathrm{mg}$, pantothenic acid: $9.200 \mathrm{mg}$, folic acid: $500 \mathrm{mg}$, selenium: $300 \mathrm{mg}$, iron: $100 \mathrm{~g}$, copper: $30 \mathrm{~g}$, manganese: $80 \mathrm{~g}$, zinc: $160 \mathrm{~g}$, iodine: $2000 \mathrm{mg}$. ${ }^{2} \mathrm{Content}$ per kg of product: 20 $\mathrm{g}$ of ractopamine (Ractosuin ${ }^{\circledR}$ ). ${ }^{3}$ Content per kg of product: $1,000 \mathrm{mg}$ of chromium (Co-Factor III ${ }^{\circledR}$ ). ${ }^{4} \mathrm{Content}$ per kg of product: $120 \mathrm{~g}$ of chromium (Cosmetrade produtos farmacêuticos). ${ }^{5}$ Values calculated based on the nutritional composition of raw materials (Rostagno et al., 2017).

FIALHO et al. (1992): EEI $=($ LCei / TCei) / 100, where LCei $=$ lowest feed cost per kilogram, and TCei $=$ treatment cost $\mathrm{i}$ considered.

The data were subjected to an analysis of variance using a general linear model procedure. When significant differences were observed, the means were compared using the SNK test. Statistical analyses were performed using the Statistical Analysis System (SAS) version 9.1, at $5 \%$ level of significance.

\section{RESULTS AND DISCUSSION}

Supplementation of the diet with yeast chromium, chromium picolinate, ractopamine, and energy restriction did not influence $(\mathrm{P}>0.05)$ the final weight, daily feed intake, crude protein, digestible lysine, and metabolizable energy (Table 2).

Feed intake is directly proportional to the energy level of the diets (GONÇALVES et al., 2016); therefore, it was speculated that a diet with energy restriction would promote an increase in feed consumption. However, this was not observed in this study, probably because the animals were able to meet their daily energy requirements without the need to increase their daily feed intake, even with the lower energy density diet.

This indicated that the energy requirement proposed by ROSTAGNO et al. (2017) may be overestimated for this category. Similar results were 
Table 2 - Performance of finishing guilts submitted to diets supplemented with ractopamine, chromium and with energy restriction.

\begin{tabular}{|c|c|c|c|c|c|c|c|}
\hline \multirow[t]{2}{*}{ Variables $^{*}$} & \multicolumn{5}{|c|}{-----------------------------------------------------Diets' } & \multirow[t]{2}{*}{$\mathrm{CV}, \%$} & \multirow[t]{2}{*}{ P-value } \\
\hline & Control & Energy restriction & Ractopamine & $\begin{array}{c}\text { Chromium } \\
\text { yeast }\end{array}$ & $\begin{array}{l}\text { Chromium } \\
\text { picolinate }\end{array}$ & & \\
\hline IW, kg & 98.54 & 99.03 & 98.83 & 99.19 & 98.76 & 8.02 & 0.999 \\
\hline $\mathrm{FW}, \mathrm{kg}$ & 122.29 & 120.29 & 127.25 & 123.91 & 119.70 & 9.31 & 0.787 \\
\hline TWG, kg & 24.36 & 24.19 & 28.42 & 24.96 & 23.28 & 12.58 & 0.061 \\
\hline DWG, kg & 1.02 & 1.01 & 1.18 & 1.04 & 0.97 & 12.56 & 0.061 \\
\hline DFI, $\mathrm{kg} \mathrm{dia}{ }^{-1}$ & 3.28 & 3.24 & 3.07 & 3.19 & 2.93 & 9.67 & 0.268 \\
\hline DICP, $\mathrm{kg} \mathrm{dia}{ }^{-1}$ & 443.06 & 437.04 & 415.01 & 430.48 & 395.88 & 9.66 & 0.267 \\
\hline DIME,kcal dia ${ }^{-1}$ & 10,995 & 10,360 & 10,298 & 10,682 & 9,824 & 9,71 & 0,349 \\
\hline DIDL, $\mathrm{g} \mathrm{dia}^{-1}$ & 26.62 & 26.26 & 24.93 & 25.86 & 23.78 & 9.66 & 0.267 \\
\hline $\mathrm{FC}$ & $3.30^{\mathrm{a}}$ & $3.24^{\mathrm{a}}$ & $2.61^{\mathrm{b}}$ & $3.08^{\mathrm{a}}$ & $3.07^{\mathrm{a}}$ & 8.82 & 0.002 \\
\hline
\end{tabular}

${ }^{1}$ Control,energetic restriction (-150 Kcal ME), $20 \mathrm{ppm}$ ractopamine, $0.8 \mathrm{ppm}$ chromium yeast, and 0.48 ppm chromium picolinate from $100-125 \mathrm{~kg}$.

*IW: initial weight; FW: final weight; TWG: total weight gain; DWG: daily weight gain, DFI: daily feed intake; DICP: daily intake of crude protein, DIME: daily intake of metabolizable energy, DIDL: daily intake of digestible lysine, FC: feed conversion.

Means followed by different letters on the line differ from one another by the SNK test $(\mathrm{P}<0.05)$.

reported by FRAGA et al. (2009), where up to $20 \%$ feed restriction in pigs in the finishing phase did not alter the daily feed intake.

The inclusion of ractopamine in the diet results in an increase in the daily weight gain of the animals at the end of the experimental period; there was a linear increase in weight gain with $0,5,10,15$, and $20 \mathrm{ppm}$ of ractopamine in diets of castrated male pigs, during the finishing phase (ARMSTRONG et al., 2004). In this study, the daily weight gain of the animals was not influenced $(\mathrm{P}=0.06)$ by the diets; however, the animals fed a diet containing ractopamine showed a gain approximately 15,16 , 13 , and $22 \%$ higher than that in the animals fed on control diet, energy restriction, yeast chromium, and chromium picolinate, respectively.

In all the evaluated diets, the gilts presented a higher average gain pattern, when compared to previously proposed estimates (ROSTAGNO et al., 2017). The greater weight gain observed in this study can be attributed to the greater consumption of daily ration and; consequently, a greater consumption of nutrients.

The effects of chromium supplementation are inconsistent, ranging from reduced feed intake in pigs fed chromium-containing diets (ALMEIDA et al., 2010), increased consumption (LIEN et al., 2001; LI et al., 2013) to no effects (MATTHEWS et al., 2006; WANG et al., 2009; SALES \& JANCIK, 2011; PERES et al., 2014), as observed in this study.
The differences in responses may be attributed to the source and level of inclusion of chromium in the diet, a fact that may lead to a greater influence on metabolism, such as reduction in feed intake.

There was no effect on feed consumption and weight gain; however, there was an effect $(\mathrm{P}<0.05)$ on feed conversion. The gilts fed with the diet supplemented with ractopamine showed improvement, compared to those fed the other diets; an improvement of approximately $21 \%$, compared to the control diet. The improvement in feed conversion in gilts that received a diet containing ractopamine, can be explained based on the gain: consumption ratio. There was a slight improvement in gain and a small reduction in consumption, improving the gain: consumption ratio; however, it was not statistically significant.

In addition, the improvement in feed efficiency may be attributed to the metabolic role of ractopamine in promoting use of dietary nutrients and; consequently, improving performance parameters, such as feed conversion (LEAL et al., 2015).

Economic evaluation indicated that the diet containing ractopamine had a lower $(\mathrm{P}<0.05)$ CWG and higher $(\mathrm{P}>0.05)$ EEI, when compared with that in the other diets. In addition, diets containing chromium and the diet with energy restriction, showed similar results, but with lower $(\mathrm{P}<0.05)$ CWG and higher $(\mathrm{P}>0.05) \mathrm{EEI}$, compared to that in the control diet. This result can be justified based 
on the nutritional efficiency for weight gain; the diet containing ractopamine was superior, compared to the other diets, and this resulted in a reduction in the cost of food.

The diets influenced $(\mathrm{P}<0.05)$ the hot carcass weight (Table 3 ); diet containing ractopamine improved the weight, much more than that in the other diets. A similar effect on the hot carcass weight was observed, when the diets of finishing pigs were supplemented with $10 \mathrm{ppm}$ ractopamine (CORASSA et al., 2010).

The diet containing $0.8 \%$ of yeast chromium improved the hot carcass weight $(\mathrm{P}<0.05)$, compared to that in the control, energy restriction, and chrome picolinate supplemented diet. This could possibly be because of the influence of chromium in animal metabolism, which enables better use of the nutrients in the diet, resulting in the conversion to a greater weight of hot carcass.

The diets did not affect $(\mathrm{P}>0.05)$ backfat thickness and muscle depth. Similarly, there is no change in the thickness of back fat in castrated male finishing pigs fed with 200 ppb of chromium sulfate and $200 \mathrm{ppb}$ of chromium methionine (PERES et al., 2014). However, there is a significant reduction in the back fat thickness with the supplementation of $200 \mu \mathrm{g}$ of chromium picolinate in the diet of males and females in the growth to finishing phases (XI et al., 2001).

The diets increased $(\mathrm{P}<0.05)$ the percentage and amount of lean meat, and the carcass bonus index; diets containing ractopamine, chromium yeast, and chromium picolinate were superior to the control and energy-restricted diets.

The higher percentage of lean meat suggested that chromium assists in the binding of target cell receptors and enhances the action of insulin, and the pig tissue apparently ends up becoming resistant to insulin (VINCENT, 2011). Therefore, it is inferred that chromium acts as an anabolic agent in the formation of muscle tissue, regulating its synthesis and promoting the increase of muscle and the amount of lean meat in the pig carcass.

This result is corroborated by Mooney \& Cromwell (1997), when analyzing pork ham, with the addition of different levels and sources of chromium (200 $\mu \mathrm{gkg}^{-1}$ of chromium picolinate and 5,000 $\mu \mathrm{gkg}^{-1}$ of chromium chloride) to the diets. GRELA et al. (1997) observed a significant increase in the proportion of lean meat in both the sexes when the animals received a diet supplemented with 0.2 and $0.5 \mathrm{mg} \mathrm{kg}^{-1}$ of organic chromium.

Pigs fed on the diet with a reduction of $150 \mathrm{kcal} \mathrm{kg}^{-1}$ of metabolizable energy exhibited good responses in terms of hot carcass weight, back fat thickness, muscle depth percentage, and amount of lean meat in the carcasses, comparable to that associated with the high performance gilts. Therefore, it is possible to reduce the energy level proposed in the recommendations (ROSTAGNO et al., 2017) for the diets, without harming the performance and carcass characteristics and with a probable reduction in feeding costs.

The improvement in the carcass bonus index observed in animals fed diets containing ractopamine and chromium can be attributed to the improvements in the percentage of lean meat and the weight of the hot carcass. The positive responses observed for both the sources of chromium confirm the hypothesis that this nutrient could be a potential substitute for ractopamine in the diets of finishing pigs.

Table 3 - Carcass traits of finishing sows submitted to diets supplemented with ractopamine, chromium and energy restriction.

\begin{tabular}{|c|c|c|c|c|c|c|c|}
\hline Variables $^{*}$ & --------- & ------------------------ & ---------Diets & - & 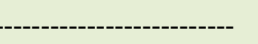 & $\mathrm{CV}, \%$ & P-value \\
\hline & Control & Energeticrestriction & Ractopamine & Chromium yeast & Chromium picolinate & & \\
\hline $\mathrm{HCW}, \mathrm{kg}$ & $91.46^{\mathrm{c}}$ & $91.03^{\mathrm{c}}$ & $95.66^{\mathrm{a}}$ & $93.63^{b}$ & $91.58^{\mathrm{c}}$ & 5.08 & 0.019 \\
\hline $\mathrm{BF}, \mathrm{mm}$ & 15.32 & 13.78 & 14.78 & 15.42 & 13.36 & 17.29 & 0,079 \\
\hline LM, \% & $53.45^{\mathrm{b}}$ & $53.40^{\mathrm{b}}$ & $55.40^{\mathrm{ab}}$ & $56.58^{\mathrm{a}}$ & $57.67^{\mathrm{a}}$ & 5.60 & 0.001 \\
\hline $\mathrm{MD}, \mathrm{mm}$ & 67.42 & 70.36 & 68.07 & 69.56 & 68.54 & 8.20 & 0.642 \\
\hline $\mathrm{BI}, \%$ & $103.20^{\mathrm{b}}$ & $103.69^{\mathrm{b}}$ & $106.36^{\mathrm{a}}$ & $106.96^{\mathrm{a}}$ & $107.46^{\mathrm{a}}$ & 2.95 & $<.0001$ \\
\hline
\end{tabular}

${ }^{1}$ Control, energetic restriction (-150 kcal ME), $20 \mathrm{ppm}$ ractopamine, $0.8 \mathrm{ppm}$ chromium yeast, and $0.48 \mathrm{ppm}$ chromium picolinate from $100-125 \mathrm{~kg}$

*HCW: hot carcass weight, BF: backfat tickness, LM: lean meat, MS: muscle depth, BI: bonification index.

Means followed by different letters on the line differ from each other by the SNK test $(\mathrm{P}<0.05)$. 


\section{CONCLUSION}

The reduction of $150 \mathrm{kcal}$ of $\mathrm{EM} \mathrm{kg} \mathrm{kg}^{-1}$ in the feed did not affect the responses of the gilts, compared to that in the control diet $(3,350 \mathrm{kcal})$. Ractopamine supplementation enables better feed conversion, lower feed cost per kilogram of gain, and a higher economic efficiency index. Supplementation with chromium picolinate, chromium yeast, and ractopamine increased the percentage and quantity of lean meat and the bonus index of the carcasses. Therefore, chromium picolinate and chromium yeast are potential substitutes for ractopamine, for optimizing the carcass characteristics of gilts.

\section{ACKNOWLEDGEMENTS}

The authors thank the Fundação de Apoio ao Desenvolvimento do Ensino, Ciência e Tecnologia do Estado de Mato Grosso do Sul (FUNDECT), Conselho Nacional de Desenvolvimento Científico e Tecnológico (CNPq), Universidade Federal de Mato Grosso do Sul (UFMS), and Coordenação de Aperfeiçoamento de Pessoal de Nível Superior - Brasil (CAPES; Finance Code 001) for the financial support in the execution of the research project.

\section{BIOETHICS AND BIOSSECURITY COMMITTEE APPROVAL}

The project was approved by the ethics committee in the use of animals, protocol number 875/2017 - Universidade Federal de Mato Grosso do Sul (UFMS).

\section{DECLARATION OF CONFLICT OF} INTEREST

The authors declare no conflict of interest. The funding sponsors had no role in the design of the study; in the collection, analyses, or interpretation of data; in the writing of the manuscript, and in the decision to publish the results.

\section{AUTHORS' CONTRIBUTIONS}

All authors contributed equally for the conception and writing of the manuscript. All authors critically revised the manuscript and approved of the final version.

\section{REFERENCES}

ALMEIDA, V. V. et al. Ractopamine, chromium-methionine and their combinations as metabolism modifier feed additives of growing and finishing pigs. Revista Brasileira de Zootecnia, v.39, p.1969-1977, 2010. Available from: <https://www.scielo. br/scielo.php?pid $=$ S1516-35982010000900015\&script $=$ sci abstract\&tlng=pt>. Accessed: Feb. 04, 2020. doi: 10.1590/S151635982010000900015 .

ALMEIDA, V. V. et al. Ractopamine as a metabolic modifier feed additive for finishing pigs: a review. Brazilian
Archives of Biology and Technology, v.3, p.445-456, 2012. Available from: $<$ https://www.scielo.br/scielo.php?pid=s151689132012000300016\&script $=$ sci_arttext $>$. Accessed: Feb. 04, 2020. doi: $10.1590 / \mathrm{S} 1516-89132012000300016$.

ARMSTRONG, T. A. et al. The effect of dietary ractopamine concentration and duration of feeding on growth performance, carcass characteristics, and meat quality of finishing pigs. Journal of Animal Science, v.82, p.3245-3253, 2004. Available from: $<$ https://academic.oup.com/jas/article/82/11/3245/4790298>. Accessed: Feb. 04, 2020. doi: 10.2527/2004.82113245x.

BELLAVER, C. et al. Malt rootlets as ration ingredients for swine on growing and finishing stages. Pesquisa Agropecuária Brasileira, v.20, p.969-974, 1985. Available from: <https:// seer.sct.embrapa.br/index.php/pab/article/view/16131/10292>. Accessed: Nov. 10, 2020.

BRIDI, A. M.; SILVA, C. A. Carcass and pork evaluation methods. Londrina, PR: Midiograf. 2007.

CARAMORI JÚNIOR, J. et al. Chromium and seleniumenriched yeast for castrated finishing pigs: effects on performance and carcass characteristics. Semina: Ciências Agrárias, v.38, p.3851-3860, 2017. Available from: <https://www.redalyc.org/ pdf/4457/445753603036.pdf $>$. Accessed: Abr. 08, 2020. doi: 10.5433/1679-0359.2017v38n6p3851.

CORASSA, A. et al. Performance, carcass characteristics and bone composition of swines fed different levels of ractopamine and phytase. Revista Brasileira de Zootecnia, v.39, p.1740-1747, 2010. Accessed: Feb. 04, 2020. Available from: <https://www. scielo.br/pdf/rbz/v39n8/v39n8a16.pdf>. doi: 10.1590/S151635982010000800016 .

COSTA, C. V. S. et al. Substitution of ractopamine by safflower or coconut oil as an additive in finishing pig diets. Ciência Rural, v.50, e20190504, 2020. Available from: <https://www.scielo.br/ pdf/cr/v50n6/1678-4596-cr-50-06-e20190504.pdf>. Accessed: Feb. 10, 2021. doi: 10.1590/0103-8478cr20190504.

EVANS, G. W.; BOWAN, T. D. Chromium picolinate increases membrane fluidity and rate of insulin internalization. Journal of Inorganic Biochemistry, v.46, p.243-250, 1992. Available from: <https://www.sciencedirect.com/science/ article/pii/016201349280034S $>$. Accessed: Feb. 04, 2020. doi: 10.1016/0162-0134(92)80034-S.

FERREIRA, M. S. S. et al. Ractopamine hidrochloride in diets for finishing pigs. Acta Scientiarum, Animal Sciences, v.33, p. 25-32, 2011. Available from: <http://periodicos.uem.br/ojs/index.php/ ActaSciAnimSci/article/view/9281>. Accessed: Feb. 04, 2020. doi: 10.4025/actascianimsci.v33i1.9281.

FIALHO, E. T. et al. Utilization of barley in diets supplemented with soybean oil for growing and finishing pigs. Pesquisa Agropecuária Brasileira, v.27, p.1467-1475, 1992. Available from: $\quad<$ https://seer.sct.embrapa.br/index.php/pab/article/ view/3793/1084>. Accessed: Nov. 10, 2020.

FRAGA, A. L. et al. Qualitative-feed-restricted heavy swine: meat quality and morpho-histochemical characteristics of muscle fibers. Brazilian Archives of Biology and Technology, v.52, p.1145-1156, 2009.Available from: $<$ https://www.scielo.br/scielo.php?pid=S1516$89132009000500012 \&$ script=sci_arttext. Accessed: Feb. 04, 2020. doi: 10.1590/S1516-89132009000500012>. 
GONÇALVES, L. M. P. et al. Net energy and ractopamine levels for barrows weighing 70 to $100 \mathrm{~kg}$. Ciência Rural, v.46, p.12681273, 2016. Available from: <http://dx.doi.org/10.1590/01038478cr20151115>. Accessed: Feb. 04, 2020. doi: 10.1590/0103$8478 \mathrm{cr} 20151115$.

GRELA, E. R. et al. Effect of a chromium yeast supplement in growing-finishing pig diets on performance, carcass traits and fatty acid composition of adipose tissue. Journal of Animal and Feed Science, v.6, p.87-100, 1997. Available from: <http://www. jafs.com.pl/Effect-of-a-chromium-yeast-supplement-nin-growingfinishing-pig-diets-on-performance-ncarcass-traits-and-fatty-acidcomposition-nof-adipose-tissue,69507,0,2.html>. Accessed: Feb. 04, 2020. doi: 10.22358/jafs/69507/1997.

LEAL, R. S. et al. Performance and carcass yield of pig fed diets containing different levels of ractopamine. Revista Brasileira de Saúde e Produção Animal, v.16, p.582-590, 2015. Available from: $\quad<$ https://www.scielo.br/pdf/rbspa/v16n3/1519-9940rbspa-16-3-0582.pdf $>$. Accessed: Feb. 04, 2020. doi: 10.1590/ S1519-99402015000300010.

LI, Y. S. et al. Effects of dietary chromium methionine on growth performance, carcass composition, meat colour and expression of colour - related gene myoglobin of growing - finishing pigs. Asian-Australasian Journal of Animal Sciences, v.26, p.10211029, 2013. Available from: <https:/www.ajas.info/upload/pdf/ ajas-26-7-1021-16.pdf> . Accessed: Feb. 04, 2020. doi: 10.5713/ ajas.2013.13012

LIEN, T. F. et al. Effect of supplemental levels of chromium picolinate on the growth performance, serum traits, carcass characteristics and lipid metabolism of growing-finishing pigs. Animal Science, v.72, p.289-296, 2001. Available from: <https:// www.cambridge.org/core/journals/animal-science/article/effectof-supplemental-levels-of-chromium-picolinate-on-the-growthperformance-serum-traits-carcass-characteristics-and-lipidmetabolism-of-growingfinishing-pigs/51CA850FFDBDAFE0 1725FD17FE14B951>. Accessed: Feb. 04, 2020. doi: 10.1017 S1357729800055788.

MAPA - Ministério da Agricultura, Pecuária e Abastecimento. 2018. Available from: < https://www.in.gov.br/materia/-/asset publisher/ Kujrw0TZC2Mb/content/id/55444279/do1-2018-12-17-instrucaonormativa-n-79-de-14-de-dezembro-de-2018-55444116>. Accessed: Nov. 20, 2020.

MATTHEWS, J. O. et al. Effects of chromium propionate on growth, carcass traits, and pork quality of growing-finishing pigs. Journal of Animal Science, v.83, p.858-862, 2006. Available from: <https://academic.oup.com/jas/article/83/4/858/4790736>. Accessed: Feb. 04, 2020. doi: 10.2527/2005.834858x.

MOONEY, K. W.; CROWELL, G. L. Efficacy of chromium picolinate and chromium chloride as potential carcass modifiers in swine. Journal of Animal Science, v.75, p.2661-2671, 1997. Available from: <https://academic.oup.com/jas/article-abstract/75 /10/2661/4638506?redirectedFrom=fulltext $>$. Accessed: Feb. 04, 2020. doi:10.252/1997.75102661x.

PARK, J. K. et al. Effects of different sources of dietary chromium on growth, blood profiles and carcass traits in growing-finishing pigs. Asian-Australasian Journal of Animal Sciences, v.22, p.1547-1554, 2009. Available from: <https://pdfs.semanticscholar. org/abc7/630096f0a3a3786588bf65083a27fcf52f54.pdf $>$. Accessed: Feb. 04, 2020. doi: 10.5713/ajas.2009.80633.

PERES, L. et al. Effect of supplementing finishing pigs with different sources of chromium on performance and meat quality. Revista Brasileira de Zootecnia, v.43, p.369-375, 2014. Available from: $<$ https://www.scielo.br/scielo.php?script=sci_arttext\&pid=S 15163598201400070036\&lng=en\&tlng=en $>$. Accessed: Feb. 04, 2020. doi: 10.1590/S1516-35982014000700005.

RICHARD, J. W. et al. Effects of ractopamine hydrochloride on the growth performance and carcass characteristics of heavy-weight finishing pigs sent for slaughter using a 3-phase marketing strategy. Translational Animal Science, v.1, p.406-411, 2017. Available from: <https://academic.oup.com/tas/article/1/3/406/4636640>. Accessed: Feb. 04, 2020. doi: 10.2527/tas2017.0053.

RODRIGUES, G. P. et al. Combined supplementation of chromium-yeast and selenium-yeast on finishing barrows. Ciência Rural, v.50, p.11, e20190406, 2020. Available from: $<$ http://doi. org/10.1590/0103-8478cr20190406>. Accessed: Aug. 05, 2020. doi: $10.1590 / 0103-8478 \mathrm{cr} 20190406$

ROSTAGNO, H. S. et al. Brazilian tables for poultry and swine: Food composition and nutritional requirements. Viçosa-MG, 4th ed., 2017. 409p.

SAAVEDRA, A. P. et al. Dietary conjugated linoleic acid (CLA) has comparable effects to ractopamine on the growth performance, meat quality and fatty acid profiles of loin muscles of finishing pigs under commercial husbandry. Italian Journal of Animal Science, v.18, p.713-722, 2019. Available from: <https:/www.tandfonline.com/doi/ full/10.1080/1828051X.2019.1568839>. Accessed: Feb. 10, 2021. doi: 10.1080/1828051X.2019.1568839.

SALES, J. A meta-analysis of the effects of dietary betaine supplementation on finishing performance and carcass characteristics of pigs. Animal Feed Science and Technology, v.165, p.68-78, 2011. Available from: <https://www.sciencedirect. com/science/article/abs/pii/S0377840111000514?via\%3Dihub>. Accessed: Feb. 10, 2021. doi: 10.1016/j.anifeedsci.2011.02.008.

SALES, J.; JANCÍK, F. Effects of dietary chromium supplementation on performance, carcass characteristics, and meat quality of growing-finishing swine: A meta-analysis. Journal of Animal Science, v.89, p.4054-4067, 2011. Available from: $<$ https://academic.oup.com/jas/article/89/12/4054/4772044>. Accessed: Mar. 08, 2020. doi: 10.2527/jas.2010-3495.

VINCENT, J. B. The Nutritional Biochemistry of Chromium. Elsevier, Amsterdam. 2011.

WANG, M. Q. et al. Efficacy of Cr (III) supplementation on growth, carcass composition, blood metabolites, and endocrine parameters in finishing pigs. Asian-Australasian Journal of Animal Science, v.22, p.1414-1419, 2009. Available from: <https:/www.ajas.info/ journal/view.php?number=22174 $>$. Accessed: Feb. 04, 2020. doi: 10.5713/ajas.2009.90111.

XI, G. et al. Effect of chromium picolinate on growth performance, carcass characteristics, serum metabolites and metabolism of lipid in pigs. Asian-Australasian Journal of Animal Sciences, v.14, p.258-262, 2001. Available from: <https://www.ajas.info/journal/ view.php?doi=10.5713/ajas.2001.258>. Accessed: Feb. 04, 2020. doi: 10.5713/ajas.2001.258. 